\title{
A COMPARATIVE STUDY OF TWO EXTREME VERSIONS OF SUBJECTIVIST CRITICISM: OSCAR WILDE'S INTENTIONS AND ANATOLE FRANCE'S LA VIE LITTÉRAIRE ${ }^{1}$
}

Cristina Pascual Aransáez Universidad de La Rioja

\section{ABSTRACT}

In the present article I carry out a comparative study of the extreme versions of subjectivist criticism which are presented in Oscar Wilde's Intentions and Anatole France's La Vie Littéraire. The purpose of this paper is to show that there may be interesting connections between Wilde's and France's critical writings. Some critics (Roditi, 1947; Woodcock, 1949; Ellmann, 1987; Kohl, 1989) have already noticed the relation of Wilde's drama La Sainte Courtisane to France's novel Thaï; nevertheless, the similarities between the critical works of the two authors have not been studied yet. I propose that Wilde and France employ the same principles in order to develop their versions of subjectivist criticism. In order to find evidence to support my view I shall examine in detail the possible parallels which may be drawn between Wilde's and France's aesthetics as expounded in Intentions and La Vie Littéraire.

1 Financial support for this research has been provided by the University of La Rioja, Research Department, grant no. API-97/A08. 
In this essay I carry out a comparative study of the extreme versions of subjectivism which are presented in Oscar Wilde's Intentions and Anatole France's La Vie Littéraire. Wilde admired the French man's works, but research on the connections between the two authors has not received much attention. The few studies ${ }^{2}$ which have scarcely noticed them (Roditi, 1947; Woodcock, 1949; Ellmann, 1987; Kohl, 1989) have focused on the similarities between Wilde's play La Sainte Courtisane and France's novel Thaïs. However, the connections between Wilde's and France's critical views have not been researched. In the present paper I shall study how both authors employ the same basic principles in order to present criticism as a subjective process and to stress the creative role of the critic against the supposed objectivity of nineteenth-century criticism. My aim is to demonstrate that a comparative study of Wilde's Intentions and France's La Vie Littéraire may be useful in order to attempt to draw several interesting points of resemblance between the critical thought of these two authors.

Both Wilde and France started to develop their critical activity in the 1880 s contributing book reviews to newspapers. By 1890 Wilde gave up journalism and went on with his critical career publishing critical essays, which were issued in 1891 with some additions and modifications in a volume entitled Intentions. The writings ${ }^{3}$ included in Intentions were 'The Decay of Lying', 'Pen, Pencil, and Poison', 'The Critic as Artist', and 'The Truth of Masks' (formerly named 'Shakespeare and Stage Costume'). In contrast to Wilde, France continued his journalistic career ${ }^{4}$, writing weekly articles for a journal called Le Temps from 1886 till 1893 . He comprised more than a hundred of them in four series entitled La Vie Littéraire (1888-1892), to which was added a posthumous volume in 1949.

In spite of the different forms which they choose to express their critical views, Wilde and France present two theories of criticism which have the same starting point and move in a similar direction: both authors reject the increasing enthusiasm for objectivity and rationalism of Positivist philosophy

2 I think it is noteworthy that these works mentioned above belong all of them to Wildean scholars. Francian critics seem to have paid no attention to the possible connections between Wilde and France. The only exception is Pierre Citti, who mentions Wilde in relation to France, stating that: «Pour tous [les deux], l'idée fondamentale est que la culture est la chose la plus importante de la vie et la moins nécessaire» («La Culture d'Anatole France ou la Mémoire Rebelle», in Bancquart and Dérens 1994: 73).

${ }^{3}$ I shall be using the following abbreviations in order to quote from Wilde's critical works: DL ('The Decay of Lying'); Pen ('Pen, Pencil, and Poison'); CA ('The Critic as Artist').

4 For details on Anatole's France extensive journalistic career, see Bancquart (1994: 42-43). 
and condemn its pervading influence on literature ${ }^{5}$. They develop theories which are based on the subjectivity and individuality of the artist and the critic and the autonomy of art and criticism. I say that Wilde and France present extreme versions of subjectivist criticism because they do not simply believe that different people see works of art slightly differently; they contend that works have no existence independent of the individuals who create or perceive them.

Since the repudiation of contemporary tendencies in literature is at the basis of Wilde's and France's criticism, I want to comment further on it before discussing the main principles of their critical theories. Wilde and France coincide in attacking Naturalism, which was the offshoot in literature of nineteenthcentury science and was a predominant movement in the 1880 s. The naturalist movement proposed a kind of literature which was scientific and positivistic, in accordance with the prestige of science in the second half of the nineteenth century. The naturalistic writer observed man and his social surroundings and analysed them in his work, in order to be able to deduce human and social laws. Both Wilde and France coincide in stressing that contrary to Naturalism's assumptions, the aim of art is not to reflect life. Wilde asserts that:

«Wherever we have returned to Life and Nature, our work has become vulgar, common, and uninteresting. (...) Facts are usurping the domain of Fancy, and have invaded the kingdom of Romance. Their chilling touch is over everything. They are vulgarising mankind». (DL, 1080-81) ${ }^{6}$

Similarly France claims that:

«Le Naturalisme tomba tout de suite dans l'ignoble. Descendu au dernier degré de la platitude, de la vulgarité, destitué de toute beauté

$s$ Due to their divergent positions with respect to the contemporary prevailing views on literature and criticism, both France and Wilde received several attacks from the French and English press respectively. Anatole France's aesthetic principles were hardly criticised by M. Ferdinand Brunetière in «La Critique Impersonnelle» (Revue des Deux Mondes, 1st January, 1891: 210-214), which led to France's defense of his critical tenets in his «Preface» to the third series of La Vie Littéraire. Oscar Wilde's critical and literary works were constantly abused by the critics and he engaged himself in a debate with the Press in 1890 after the latter's violent reactions to The Picture of Dorian Gray (see Beckson, 1998: 67-71 and Letters of Oscar Wilde, ed. Hart-Davis, 1962: 295313). Significantly enough for our comparative study, most critics identified the spirit of Wilde's works as both «modern and French» (Haley, 1985: 229).

${ }^{6}$ The quotations from Oscar Wilde's critical works will be taken from Complete Works of Oscar Wilde, 1994 (1948), Glasgow: HarperCollins. 
intellectuelle et plastique, laid et bête, il dégoûta les délicats». (VL, 1st series: 508$)^{7}$

Émile Zola (1840-1902), who was the main conspicuous representative of naturalism, became the main object of Wilde's and France's attacks. Wilde criticises Zola and his work thus:

«M. Zola, true to the lofty principle that he lays down in one of his pronunciamientos on literature, L'homme de génie n'a jamais d'esprit, is determined to show that, if he has not got genius, he can at least be dull. And how well he succeeds! (...) His work is completely wrong from beginning to end (...) The author is perfectly truthful, and describes things exactly as they happen. (...) But from the standpoint of Art, what can be said in favour of the author of $L^{\prime}$ Assommoir, $\mathrm{Na}$ $n a$ and Pot-Bouille? Nothing. (...) In literature we require distinction, charm, beauty and imaginative power». (DL, 1075)

France accuses Zola of offending beauty with his «irrémédiable grossièreté» (VL, 1st series: 345$)$ and of representing nature according to the teachings of science, making of himself «une botanique, une chimie, une physiologie de la plus mauvaise qualité», concluding that:

«Quand M. Zola parle pour son propre compte, il est bien lourd et bien mou. (...) La grâce des choses lui échappe, la beauté, la majesté, la simplicité le fuient à l'envi. (...) Son oeuvre est mauvaise et il est un de ces malheureux dont on peut dire qu'il vaudrait mieux qu'ils ne fussent pas nés». (VL, 1st series: 210,213 )

The basic principle of Wilde's and France's criticism is the rejection of the subjective/objective distinction. Both of them argue that works are inevitably subjective and they do it in very similar grounds:

"The difference between objective and subjective work is one of external form merely. It is accidental, not essential. All artistic creation is absolutely subjective. (...) For out of ourselves we can never pass». (CA, 1142)

"Il n'y a pas plus de critique objective qu'il n'y a d'art objectif, et tous ceux qui se flattent de mettre autre chose qu'eux-mêmes dans

7 Unless otherwise indicated, the quotations from Anatole France's La Vie Litteraire will be taken from Ouevres Completes Illustrés de Antole France, 1926, 4 vols, Paris: Calmann-LEvy. 
leur oeuvre sont dupes de la plus fallacieuse illusion. La vérité est qu'on ne sort jamais de soi-même». (VL, 1st series: 5)

They even coincide in reaching the seemingly paradoxical conclusion that the objective form is subjective in matter:

«Man is least himself when he talks in his own person. Give him a mask, and he will tell you the truth». (CA, 1142)

«Les plus grands n'ont pas fait davantage. Ils n'ont parle que d'eux. Sous de faux noms, ils n'ont montré qu'eux mêmes». (VL, 1st series, 99)

As Bashford (1977: 182; $1978: 219)$ rightly points out, Wilde applies this observation that a work is at least partially a projection of its author not only to art, but to discourse in any intellectual realm. This is the reason why Wilde regards the literary critic as a creator in his own right, which leads him to extremes of subjectivism, as in the following passage:

"That's what the highest criticism really is, the record of one's own soul. It is more fascinating than history (...), it is more delightful than philosophy (...) It is the only civilised form of autobiography». (CA, 1125)

This extreme subjectivism is also to be found in France's conception of criticism and the critic. There are striking similarities between Wilde's passage above and the following passage by France:

«(...) la critique est, comme la philosophie et l'histoire, une espèce de roman à l'usage des esprits avisés et curieux, et tout roman, à le bien prendre, est une autobiographie. (...) Le bon critique est celui qui raconte les aventures de son âme au milieu des chefs-d'oeuvre». (VL, 1st series: 7)

This point of resemblance between Wilde and France is peculiarly worthy of note because of the way it throws into relief how strong the versions they hold of subjectivist criticism are. Wilde states that «the first step in aesthetic criticism is to realise one's own impressions» (Pen, 1096), and contends that it is the critic

«who lends to the beautiful thing its myriad meanings, and makes it marvellous for us. (...) To the critic the work of art is simply a 
suggestion for a new work of his own, that need not necessarily bear any obvious resemblance to the thing it criticises ${ }^{8}$. The one characteristic thing of a beautiful form is that one can put into it whatever one wishes, and see in it whatever one chooses to see». (CA, 1127, 1128)

France equally stresses the creative and independent role of the critic, who must, in France's own words:

"déployer moins de raison, surtout moins de raisonnement; (...) de s'arrêter où l'on se plaît et de faire parfois des confidences; de garder dans la critique le ton familier de la causerie et le pas léger de la promenade; de s'arrêter où l'on se plaît et de faire parfois des confidences; de suivre ses goûts, ses fantaisies et même son caprice (...); de ne pas tout savoir et de ne pas tout expliquer; de croire à l'irrémédiable diversité des opinions et des sentiments et de parler plus volontiers de ce qu'il faut aimer». $(V L, 3$ rd series: 14$)$

It is particularly significant to examine one of the requirements for the critic which France mentions in the passage above, namely, that he must believe in «l'irrémédiable diversité des opinions et des sentiments». This indicates that France defends a subjectivist criticism which is not limited to the critic's realm, but extends to encompass all the receivers of a work of art. This idea is even more explicitly stated in the following statement: «Il faut que le critique se pénètre bien de cette idée que tout livre a autant d'exemplaires différents qu'il a de lecteurs» (VL, 2nd series: 332 ).

Wilde also believes that there exists no definite interpretation of any work of art and he contends that there are «as many meanings as man has moods» (CA, 1127). This belief leads Wilde to conclude that «there are as many Hamlets as there are melancholies" (CA, 1131). France reaches a similar conclusion as regards Virgil: «(...) que dans le même pays deux hommes sentent absolument de la même façon tel vers de Virgile, rien n'est moins probable» $(V L, 3 \text { rd series: } 11)^{9}$.

The similarities between the precepts of both critics can be stretched further. In both Wilde's and France's critical theories, the complete departure from

${ }^{8}$ Nonetheless Wilde admits later on in his essay that «some resemblance, no doubt, the creative work of the critic will have to the work that has stirred him to creation» (CA, 1129).

${ }^{9}$ As Wellek (1986: 38) and Yllera (1996: 257) have rightly pointed out, in spite of France's apparent tolerance towards others's tastes and opinions, his judgments on contemporary writers whom he did not like were as harsh as that of any other critic. The same can be said with respect to Oscar Wilde's literary judgments on other authors, even if his tone was milder that France's. France's and Wilde's hostile comments on Zola quoted above (p. 298) illustrate this point. 
objectivity in criticism is reinforced by their vision of art, which contributes to give coherence to their critical positions. These two authors regard Beauty as an essential element of a work of art, and both coincide in conceiving it as something which is never fully realized: Wilde believes that «Beauty reveals everything, because it expresses nothing» (CA, 1127), and France asserts that «la beauté (...) garder[a] à jamais [son] secret» (VL, 3rd series: 13). Consequently the works of art which they consider to be beautiful are characterized by the sense of vagueness that they associate with Beauty. All this is directly connected with their versions of subjectivist criticism, because it is precisely these works which stimulate the critic to exert his creative faculty. Wilde asserts that:

"You see, then, how it is that the aesthetic critic rejects these obvious modes of art that have but one message to deliver, and having delivered it become dumb and sterile, and seeks rather for such modes as suggest reverie and mood, and by their imaginative beauty make all interpretations true, and no interpretation final». (CA, 1129)

A similar statement is made by France:

«Je m'efforcerai de garder comme un don céleste l'impression de mystère que me causent les sublimités de la poésie et de l'art. (...) Tous les livres en général et même les plus admirables me paraissent infiniment moins précieux par ce qu'ils contiennent que par ce qu'y met celui qui les lit. Les meilleurs, à mon sens, sont ceux qui donnent le plus à penser, et les choses plus diverses». (VL, 2nd series: 331$)$

A further element of Wilde's and France's theories is the method of applying the principle of subjectivity of the critic, which in both cases is related to the value these authors put on individuality. For Wilde resting self-satisfied is a way of restraining the general growth of the individual, and according to him the only solution to avoid it is to continue to search for the new. As regards criticism, this means that the critic "will ever be curious of new sensations and fresh points of view» (CA, 1144), and that he "will not consent to be the slave of his own opinions» (CA, 1145). France believes in the same method in order to avoid the stagnation of the critic, and claims that « [nous] aimons les livres qui nous plaisent (...) en convenant avec nous-mêmes que notre impression d'aujourd'hui n'engagera point celle de demain» (Les Contemporains, II, Fayolle, 1964: 132).

Both Wilde and France coincide in pointing out that this subjectivist behaviour of the critic towards the work of art will have a direct consequence on the presentation of classic masterpieces: 
«He [the critic] will always be showing us the work of art in some new relation to our age. He will always be reminding us that great works of art are living things - are, in fact, the only things that live». $(\mathrm{CA}, 1132)$

"Chaque génération d'hommes cherche une émotion nouvelle devant les ouvrages des vieux maîtres». (Le Jardin d'Epicure, Fayolle, 1964: 130)

Let us look closely at Wilde's and France's views on criticism in the narrower sense of commentary on particular authors and works, where they fare slightly differently:

Both Wilde and France believe that the aim of the critic does not consist in clarifying a work of art: Wilde sees reason and recognition as stages of apprehension subordinated to «a pure synthetic impression of the work of art as a whole ${ }^{10}$ (CA, 1128); France regards sentiment and reason as the only instruments to study a work of art, and he adds that these are «les instruments les moins précis qui soient au monde» ( $V L, 2$ nd series: 30 ).

However, Wilde recommends the traditional scholarly study of an author and his works:

«Ordinary people are 'terribly at ease in Zion.' They propose to walk arm in arm with the poets, and have a glib ignorant way of saying, 'Why should we read what is written about Shakespeare and Milton? We can read the plays and the poems. That is enough.' But an appreciation of Milton is (...) the reward of consummate scholarship.» (CA, 1130)

This remark may seem surprising at first in the light of the subjectivism of his critical theory. Nevertheless, it does not contradict Wilde's basic principles, because the critic will not use his learning as a simple clarification of the work but as a background against which he will bring his creative activity to the fore:

«The critic (...) will not treat Art as a riddling Sphinx, whose shallow secret may be guessed and revealed by one (...). Rather, he will

10 Here Wilde is referring to the critic as a creator, but he believes that the critic can also choose to limit himself to analyse the work itself: «He [the critic] can pass from his synthetic impression of the work of art as a whole, to an analysis or exposition of the work itself» (CA, 1130). However, he considers it to'be a "lower sphere» and insists that the critic's object «will not always be to explain the work of art. He may seek rather to deepen its mystery, to raise round it, and round its maker, that mist of wonder which is dear to both gods and worshippers alike» (CA, 1130). 
look upon Art as a goddess whose mystery it is his province to intensify, and whose majesty his privilege to make more marvellous in the eyes of men». (CA, 1130)

In contrast to Wilde, France makes no reference to the critic's need of possessing any previous knowledge of scholarship of a work in order to criticise it. However, it must be stressed that this distinction between Wilde and France does not affect the basic similar nature of their critical theories, because as we have seen both authors employ the same principles in order to develop their versions of subjectivist criticism. Moreover, it must be noted that despite France's apparent indifference to scholarly knowledge about the works to critici$z e$, his friends affirm that they provide him with aboundant information for each of his articles (Vandegans, 1954: 298).

Finally, it would be interesting to comment on another similarity between Wilde's and France's theories. Wilde adds a last qualification for the critic, which emphasises the subjectivism of his criticism: the critic must intensify his personality, because, in Wilde's own words:

«The more strongly this personality enters into the interpretation, the more real the interpretation becomes, the more satisfying, the more convincing, an the more true. (...) If you wish to understand others you must intensify your own individualism.» (CA, 1131)

This qualification for the critic can also be found in France's critical theory. France shares with Wilde the belief that «la critique (...) la plus personnelle est la plus intéressante» (VL, 2nd series: 176).

So far little attention has been paid to the connections between Oscar Wilde's and Anatole France's works, and the similarities between their lines of critical thought have scarcely been noticed. In the foregoing analysis I have carried out a comparative study of Wilde's Intentions and France's La Vie Litterraire, with the aim of providing evidence that there may be interesting points of resemblance between the extreme versions of subjectivist criticism of these authors. I have analysed the possible correspondences between Wilde's and France's aesthetics, and the results have confirmed that, in spite of some slight differences, there were several parallels between Wilde's and France's proposals.

Thus, it can be concluded that there is ample proof that Wilde and France hold the same basic position on the subjective nature of criticism and they employ similar principles which emphasise the creative faculty of the critic of a work of art. It may be possible to think that the present study might contribute 
to encourage further research on the connections between Wilde's and France's works, because the conclusions reached after it seem to suggest that this topic could make for a fruitful field of research.

\section{BIBLIOGRAPHICAL REFERENCES}

BANCQUART, Marie-Claire (1994): Anatole France. Paris: Julliard.

BANCQUART, Maire-Claire \& Jean DERENS, eds. (1994): Anatole France: Humanisme et Actualité. Actes du Colloque pour le cent cinquantième anniversaire de la mort d'Anatole France. Paris. Bibliothèque Historique de la Ville de Paris.

BASHFORD, Bruce (1977): «Oscar Wilde, His Criticism and His Critics». English Literature in Transition, 20, 4, 181-187.

- (1978): «Oscar Wilde and Subjectivist Criticism». English Literature in Transition, 21, 4, 218-234.

BeCKson, Karl, ed. 1998 (1974): Oscar Wilde: The Critical Heritage. London: Routledge and Kegan Paul.

EllmanN, Richard (1987): Oscar Wilde. London: Hamish Hamilton.

FAYOLLE, Roger (1964): La Critique Littéraire. Paris: Armand Colin.

FRANCE, Anatole (1926): Ouvres Complètes Illustrés de Anatole France. 4 vols. Paris: Calmann-Lévy.

Haley, Bruce (1985): «Wilde's «Decadence» and the Positivist Tradition». Victorian Studies, XXVIII, 2, 215-229.

HART-Davis, Rupert, ed. (1962): The Letters of Oscar Wilde. London: Hart-Davis. KoHL, Norbert. 1989 (1980): Oscar Wilde: Das literarische Werk zwischen Provokation und Anpassung. Heidelberg: Carl Winter. Translated as Oscar Wilde: The Work of a Conformist Rebel., D. H. Wilson. Cambridge: Cambridge University Press.

RoDIT, Edouard (1947): Oscar Wilde. Norfolk, CT: New Directions Books.

VANDEGans, André (1954): Anatole France: Les Années de Formation. Paris: Nizet. WELLEK, René (1986): A History of Modern Criticism: 1750-1950: The Second Half of the Nineteenth Century. New Haven, London: Yale University Press.

WILDE, Oscar 1994 (1948): Complete Works of Oscar Wilde. Glasgow: HarperCollins.

WoodCoCK, George (1949): The Paradox of Oscar Wilde. London: T. V. Boardman. YLLERA, Alicia (1996). Teoría de la Literatura Francesa. Madrid: Síntesis. 